\title{
SEPARATION AND PRECONCENTRATION TRACE AMOUNTS OF GOLD BY USING MODIFIED ORGANO NANOCLAY CLOSITE 15A
}

\author{
Sayed Zia Mohammadi* and Naimeh Seifollahi \\ Department of Chemistry, Payame Noor University, Kerman, Iran \\ Daryoush Afzali
}

Nanochemistry and Environment Department, Research Institute of Environmental Sciences, International Center for Science, High Technology \& Environmental Sciences, Kerman, Iran

Recebido em 7/10/09; aceito em 14/3/10; publicado na web em 20/7/10

\begin{abstract}
The application of organo nanoclay 5-(4-dimethylamino-benzylidene) rhodanine-immobilized as a new, easily prepared, and stable solid sorbent for preconcentration trace amounts of $\mathrm{Au}(\mathrm{III})$ ions in aqueous solution is presented. The sorption of $\mathrm{Au}(\mathrm{III})$ ions was quantitative in the $\mathrm{pH}$ range of 2-4, and quantitative desorption occurred instantaneously with $10.0 \mathrm{~mL}$ of a mixture containing 0.5 mol L-1 $\mathrm{Na}_{2} \mathrm{~S}_{2} \mathrm{O}_{3}$ and $\mathrm{KSCN}$. Various parameters, such as the effect of $\mathrm{pH}$, breakthrough volume, extraction time, and interference of a large number of anions and cations have been studied. The proposed method has been applied for determination of trace amount of gold in water samples.
\end{abstract}

Keywords: nanoclay; preconcentration; gold determination.

\section{INTRODUCTION}

Gold belongs to the group of elements which occur on the Earth in very low natural contents. The concentration of gold in natural water is extremely low, ${ }^{1}$ in the range from 0.01 to $10 \mathrm{ng} \mathrm{L}^{-1}$. It is well known that gold is one of the most interesting micro amount elements due to its significant role on biology, environment and industry. Even though it could be used as the drug in the supervised therapy of arthritis and cancer $^{2}$ in the form of different $\mathrm{Au}(\mathrm{I})$ and $\mathrm{Au}(\mathrm{III})$ compounds, or in radiotherapy of cancer in the form of radioactive isotope ${ }^{198} \mathrm{Au}$. It could be also very toxic for human and animal organism and plants and account as the pollutant, because of its inhibiting effect upon the activity of many enzymes and its preventing effect upon the DNA separation. ${ }^{2}$ Numerous methods for gold determination are known: spectrometric methods, ${ }^{1} \mathrm{UV}$-Vis spectrophotometry, ${ }^{2,3}$ electrothermal atomic absorption spectrometry (ETAAS), ${ }^{4}$ inductively coupled plasma combined with optical emission spectrometry (ICP-OES) $)^{5,6}$ or mass spectrometry (ICP-MS $)^{7}$ were applied for a variety of samples in the analysis of gold.

The detection limits offered by UV-VIS, however, make the technique applicable only to the determination of relatively higher concentrations (microgram per gram levels) as compared to ETAAS, ICP-OES or ICP-MS. ${ }^{3,8}$ The last technique is particularly suited to the determination of gold in various matrices owing to the low detection limits (picogram levels), wide dynamic range, possibility of accurate multi-element analysis, a unique capability of measuring isotopic ratios. Other sensitive techniques such as neutron activation analysis ${ }^{9}$ or total reflection X-ray fluorescence spectrometry (TXRF) ${ }^{10}$ are less often applied in gold analysis due to the complexity and cost of the required instrumentation. In environmental, geological and biological samples, the low concentration of gold together with the high concentration of interfering matrix components often require an enrichment step combined with a matrix separation. Among the numerous techniques reported for preconcentration and matrix separation of gold, the methods using sorbent extraction have proved to be especially effective. ${ }^{11}$ A number of different sorbents have been investigated

\footnotetext{
*e-mail: szmohammadi@yahoo.com
}

for the preconcentration and separation of trace gold. They include activated carbon, ${ }^{12}$ chelating resins with selective functional groups covalently attached to copolymer matrices ${ }^{6}$ ligand-modified silica gel $^{7}$ and cotton fibers. ${ }^{13}$

In recent years, great attention has been paid to the application of nano structure materials. Because clay and clay minerals have primary particles with at least one dimension in the nanometer scale, they may be regarded as nanomaterials of geological and pedological origin. ${ }^{14}$

Clays are hydrous aluminosilicates broadly defined as those minerals that make up the colloid fraction $(<2 \mu \mathrm{m})$ of soils, sediments, rocks and water. ${ }^{15}$ The particles of clay minerals may be crystalline or amorphous, platy or fibrous and may vary from colloid dimensions to those above the limit resolution of an ordinary microscope ${ }^{16}$ Clay structure is layered with interlayer space and the layers may be electrically neutral or charged. The high specific surface area, chemical and mechanical stability, variety of structural and surface properties, higher values of cation exchange capacities, etc., make the clays an excellent group of adsorbents. Intercalation of clays cross-linked with inorganic or organic clusters, known as pillared interlayered clays (PILC) or crosslinked clays (CLC) has received wide attention recently as shape-selective catalysts, separating agents, supports, adsorbents, etc. These materials have a two-dimensional pore size larger than conventional zeolites and exhibit specific properties depending on the nature of the pillar. ${ }^{17}$ These materials are usually prepared by ion-exchanging cations in the interlayer region of swelling clays with bulky alkylammonium ions, polynuclear complex ions bearing inorganic ligands (hydroxo ligand, chloro ligand), large metal complex ions bearing organic ligands, etc.

A large number of studies have been reported on use of clays for metal ion removal from aqueous solution: $\mathrm{Zn}$ (II) with natural bentonite, ${ }^{18}$ and illite, ${ }^{19} \mathrm{Mn}(\mathrm{II}), \mathrm{Co}(\mathrm{II}), \mathrm{Ni}(\mathrm{II})$ and $\mathrm{Cu}(\mathrm{II})$ with raw kaolin, ${ }^{20}$ $\mathrm{Co}$ (II) with sepiolite, ${ }^{21}$ etc. Various forms of modified clays have also been used: $\mathrm{Na}$-exchanged bentonites for $\mathrm{Cr}$ (III), $\mathrm{Ni}$ (II), $\mathrm{Zn}$ (II), $\mathrm{Cu}$ (II) and $\mathrm{Cd}(\mathrm{II}),{ }^{22}$ surfactant modified montmorillonite for $\mathrm{Cu}(\mathrm{II})$ and $\mathrm{Zn}(\mathrm{II}){ }^{23} 1: 10$ phenanthroline-grafted Brazilian bentonite for $\mathrm{Cu}(\mathrm{II}){ }^{24}$

The aim of the described research was to develop a new sorbent for separation and preconcentration of trace amounts of gold. In recent work, Ko et al..$^{25}$ and Richards et al. ${ }^{26}$ found that organo nanoclay 
could adsorb organic substances. Therefore, the rhodanine was added to organo nanoclay, and the rhodanine-immobilized organo nanoclay was then studied for separation and preconcentration of $\mathrm{Au}(\mathrm{III})$ ion. The results showed that the rhodanine-immobilized organo nanoclay was suitable for separation and preconcentration of trace amounts of $\mathrm{Au}$ (III) (recoveries were $>96 \%$ ).

\section{EXPERIMENTAL}

\section{Instrumentation}

A SensAA GBC atomic absorption spectrometer equipped with deuterium background correction and gold hollow-cathode lamp was used for absorbance measurements at wavelength of $242.8 \mathrm{~nm}$ according to instrument instruction. The instrumental parameters were adjusted according to the manufacturer's recommendations. A Metrohm $692 \mathrm{pH}$ meter was used for $\mathrm{pH}$ measurements. An IKA stirrer model KS 130B was used for stirring of samples. All glassware was washed before use with a mixture of concentrated $\mathrm{HCl}$ and concentrated $\mathrm{HNO}_{3}(1: 1)$.

\section{Reagents and solutions}

All chemicals were of analytical-reagent grade and were used without previous purification. Nanoclay closite 15A was prepared from southern clay product (Gonzales, Texas, USA). Stock solution of gold at a concentration of $1000.0 \mu \mathrm{g} \mathrm{mL}{ }^{-1}$ was prepared by dissolving an appropriate amount of $\mathrm{HAuCl}_{4} \cdot 3 \mathrm{H}_{2} \mathrm{O}$ (Merck, Darmstadt, Germany) in double distilled water and diluting to $1.0 \mathrm{~L}$. Working reference solutions were prepared daily by stepwise dilution from stock solution. A $0.2 \%(\mathrm{w} / \mathrm{v})$ solution of 5-(4-dimethylamino-benzylidene) rhodanine (Merck, Germany) was prepared by dissolving in ethanol. Buffer solution with $\mathrm{pH} 3.5$ was prepared from $0.2 \mathrm{~mol} \mathrm{~L}^{-1}$ acetic acid and $0.2 \mathrm{~mol} \mathrm{~L}^{-1}$ sodium acetate. Solutions of alkali metal salts $(1 \%)$ and various metal salts $(0.1 \%)$ were used in order to test the interference of anions and cations, respectively.

\section{Preparation of rhodanine -immobilized organo nanoclay}

Nanoclay closite 15 A dispersed in a $0.2 \%(w / v)$ solution of rhodanine in ethanol with stirring at $480 \mathrm{rpm}$ for $5 \mathrm{~h}$. The excess rhodanine solution was then decanted and the resultant organo nanoclay was washed sequentially several times with distilled water to remove excess of rhodanine and then dried at $110^{\circ} \mathrm{C}$.

\section{Preconcentration procedure}

An aliquot of $\mathrm{Au}(\mathrm{III})$ containing 1.0-250.0 $\mu \mathrm{g} \mathrm{Au}(\mathrm{III})$ was adjusted to $\mathrm{pH} \sim 3.5$, and then $0.1 \mathrm{~g}$ rhodanine -immobilized organo nanoclay was added to it with stirring at $480 \mathrm{rpm}$ for $5 \mathrm{~min}$. The solid mass was separated by filtration through filter paper No. 1041 (Whatman Inc., Florham Park, NJ). At the end, the separated solid was washed with distilled water. The adsorbed metal ions were eluted with $10.0 \mathrm{~mL}$ of a mixture containing $0.5 \mathrm{~mol} \mathrm{~L}^{-1} \mathrm{Na}_{2} \mathrm{~S}_{2} \mathrm{O}_{3}$ and KSCN (1:1 ratio). The eluent was diluted in a $10.0 \mathrm{~mL}$ volumetric flask and aspirated directly into the flame of the AAS instrument for measurement against a blank prepared in the same manner without the addition of metal ions.

\section{RESULTS AND DISCUSSION}

In this study, combination of SPE with FAAS was developed for determination trace amounts of gold. It is based on the metal- che- late formation of gold and rhodanine and extraction from aqueous solution. At first, buffer and sample solution were added to $0.1 \mathrm{~g}$ of rhodanine-immobilized organo nanoclay. In this step, gold ions reacted with rhodanine-immobilized for Au-rhodanine formation, then the solid mass was separated by filtration and the adsorbed metal ions were eluted with a mixture containing $0.5 \mathrm{~mol} \mathrm{~L}^{-1} \mathrm{Na}_{2} \mathrm{~S}_{2} \mathrm{O}_{3}$ and KSCN. Several factors that may affect the preconcentration and extraction process, including $\mathrm{pH}$, type and volume of elution solution, extraction time, sample volume and matrix effect were studied and optimized. The optimizations were carried out on aqueous solution containing $50.0 \mu \mathrm{g}$ of gold ions.

\section{Effect of pH on preconcentration}

The $\mathrm{pH}$ plays a unique role on metal-chelate formation and subsequent extraction, and is proved to be a main parameter for preconcentration. Extraction yield depends on the $\mathrm{pH}$ at which complex formation is carried out. In this view, $50.0 \mu \mathrm{g}$ of gold was studied in the $\mathrm{pH}$ range of 2-8. The recovery percent of gold ions are shown in Figure 1, and as can be seen at $\mathrm{pH}$ less than 4, the gold ions were quantitatively $(>97 \%)$ retained on the sorbent. When $\mathrm{pH}>4$, the formation of $\mathrm{Au}(\mathrm{OH})_{3}$ could be happened and the recoveries percent were decreased. Therefore, a $\mathrm{pH}$ of 3.5 in the middle of the $\mathrm{pH}$ range was considered as being the optimum value to avoid an abrupt change in adsorption, which may occur due to minor changes in the $\mathrm{pH}$.

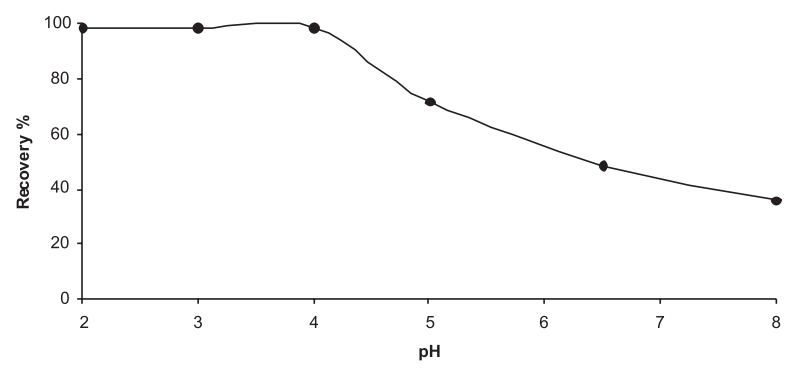

Figure 1. Effect of pH on recovery of Au (III) ions. Conditions: Au (III), 50.0 $\mu \mathrm{g}$; sorbent, $0.1 \mathrm{~g}$; extraction time, $5 \mathrm{~min}$; stirring, $5 \mathrm{~min}$ at $480 \mathrm{rpm}$

Addition of 2-20 $\mathrm{mL}$ buffer did not have any effect on the extraction. Therefore, $5 \mathrm{~mL}$ buffer with $\mathrm{pH} \sim 3.5$ was used in all subsequent experiments.

\section{Effect of extraction time on preconcentration}

The gold extraction was also studied as a function of extraction time at the optimum condition. The gold concentration was kept at $5.0 \mu \mathrm{g} \mathrm{mL}^{-1}$ and gold extraction yield was measured by varying the equilibrium extraction time in the range of 2-30 min. The extraction efficiency of gold is plotted in Figure 2. This figure shows that the reaction of gold and rhodanine is fast and after $5 \mathrm{~min}$, gold extraction by sorbent reached to equilibrium. Therefore, extraction time $5 \mathrm{~min}$ was used in all subsequent experiments.

\section{Effect of the breakthrough volume on preconcentration}

The measurement of breakthrough volume is important in solid phase extraction because breakthrough volume represents the sample volume that can be preconcentrated without loss of analyte during elution of the sample. For this purpose, 30, 60, 100, 250, 500, 700 and $800 \mathrm{~mL}$ of aqueous solution containing $50.0 \mu \mathrm{g}$ of $\mathrm{Au}$ (III) ions were processed according to the preconcentration procedure. The results are given in Table 1 and shown that, gold ions were recovered quantitatively in the 


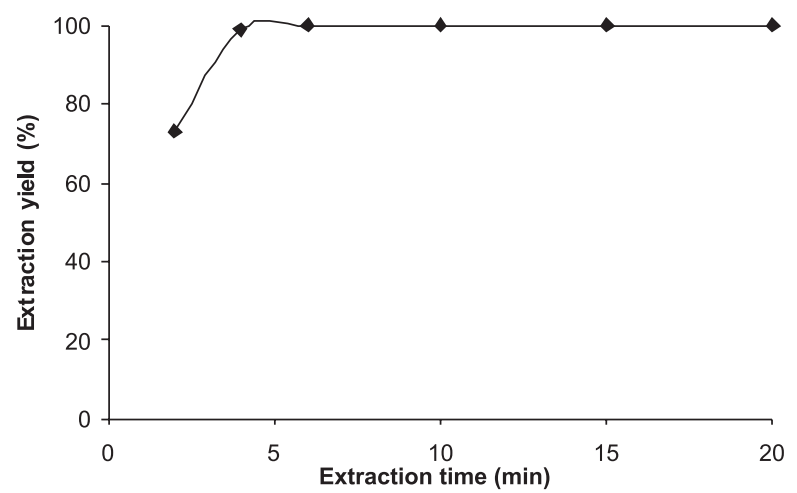

Figure 2. Effect of extraction time on recovery of Au (III) ions. Conditions were the same as Figure 1

range of $30-700 \mathrm{~mL}$. With respect to eluent volume $(10 \mathrm{~mL})$, preconcentration factors (the ratio of the highest sample volume to the lowest eluent volume) for gold ions 70 were obtained. However, for convenience, all the experiments were performed with $40 \mathrm{~mL}$ of the aqueous phase.

Table 1. Influence of the sample volume on the recovery of gold ions

\begin{tabular}{cc}
\hline Sample volume $(\mathrm{mL})$ & Recovery $(\%)$ \\
\hline 30 & 99 \\
60 & 99 \\
100 & 98 \\
250 & 97 \\
500 & 97 \\
700 & 95 \\
750 & 90 \\
\hline
\end{tabular}

\section{Choice of eluente}

Another important factor which affects the preconcentration procedure is the type, volume and concentration of the eluent used for the removal of analytes from the sorbent. Optimization of the elution conditions were performed in order to obtain the maximum recovery with the minimal concentration and volume of the eluent solution. In order to, a number of eluents were tested to desorbed gold ions from the sorbent. Organic solvents can be used as eluents, but they removed the rhodanine reagent. If inorganic solutions were used as eluents, the rhodanine reagent was retained on the sorbent and, therefore, allowed it to be used several times.

The gold ions were stripped with $10.0 \mathrm{~mL}$ of different concentrations of various eluent solutions. The results are shown in Table 2 and were shown that, the $\mathrm{Au}(\mathrm{III})$ ions were quantitatively eluted from the sorbent only with a mixture containing $0.5 \mathrm{~mol} \mathrm{~L}^{-1} \mathrm{Na}_{2} \mathrm{~S}_{2} \mathrm{O}_{3}$ and $\mathrm{KSCN}$ (1:1 ratio). Therefore, $10.0 \mathrm{~mL}$ of this mixture was used in all subsequent experiments.

\section{Analytical figures of merit}

Repeatability, linearity, and detection limit were investigated under the optimized experimental conditions. The calibration graph was linear in the range of $0.1-25.0 \mu \mathrm{g} \mathrm{mL}^{-1}$ in final solution (Figure 3 ) and 1.43-357.14. $\mathrm{ng} \mathrm{mL}^{-1}$ in the original solution. The detection limit (calculated as three times the standard deviation of 8 blank measurements, divided by the slope of the calibration curve) for gold determination was found to be $42.6 \mathrm{ng} \mathrm{mL}^{-1}$. The repeatability was evaluated with $40.0 \mathrm{~mL}$ of a aqueous solution contain $50.0 \mu \mathrm{g} \mathrm{Au}(\mathrm{III})$. The relative standard deviation (R.S.D.) for 8 replicate measurements was $1.7 \%$. Sensitivities for $1 \%$ absorbance for $\mathrm{Au}(\mathrm{III})$ was $93.4 \mathrm{ng}$
Table 2. Effect of type and concentration of eluent on the recovery of the $\mathrm{Au}(\mathrm{III})$ ions

\begin{tabular}{cc}
\hline Eluent $(10 \mathrm{~mL})$ & Recovery $(\%)$ \\
\hline $\mathrm{HNO}_{3}, 0.5 \mathrm{~mol} \mathrm{~L}^{-1}$ & 19 \\
$\mathrm{HNO}_{3}, 1.0 \mathrm{~mol} \mathrm{~L}^{-1}$ & 34 \\
$\mathrm{HCl}, 0.5 \mathrm{~mol} \mathrm{~L}^{-1}$ & 28 \\
$\mathrm{HCl}, 1.0 \mathrm{~mol} \mathrm{~L}^{-1}$ & 39 \\
$\mathrm{KSCN}, 0.5 \mathrm{~mol} \mathrm{~L}^{-1}$ & 61 \\
$\mathrm{Na}_{2} \mathrm{~S}_{2} \mathrm{O}_{3}, 0.5 \mathrm{~mol} \mathrm{~L}^{-1}$ & 53 \\
$\mathrm{Na}_{2} \mathrm{~S}_{2} \mathrm{O}_{3}$ and $\mathrm{KSCN}_{0.5 \mathrm{~mol} \mathrm{~L}^{-1}(1: 1 \mathrm{ratio})}$ & 98 \\
\hline
\end{tabular}

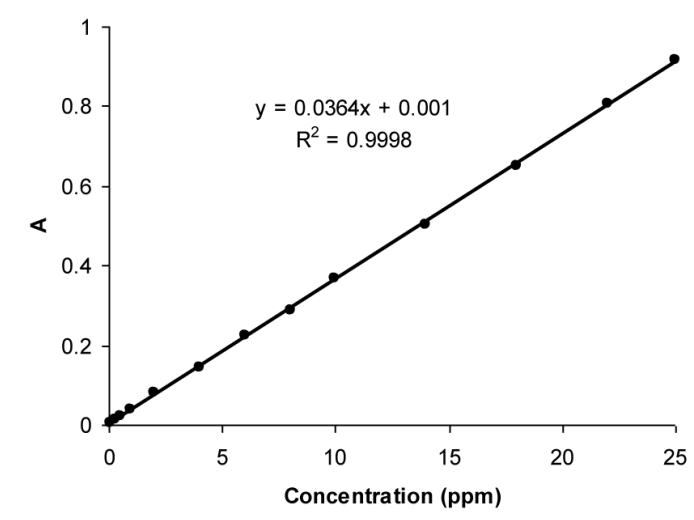

Figure 3. Calibration curve. Conditions were the same as Figure 1, except Au (III) amount

$\mathrm{mL}^{-1}$. The preconcentration factors as the ratio of initial volume to final volume and was 70 .

\section{Effect of foreign ions}

In view of the high selectivity provided by flame atomic absorption spectrometry, the only interference may be attributed to the preconcentration step, in which the cations may react with rhodanine which may lead to decrease in extraction efficiency. Interferences studied were those related to the preconcentration step, cations that may react with rhodanine or species that may react with analytes and decrease the extraction efficiency. To perform this study, interferents ion in different interferents-to-analyte ratios were added to a solution containing $50.0 \mu \mathrm{g}$ of $\mathrm{Au}(\mathrm{III})$ and were subjected to the recommended procedure. Table 3 shows the tolerance limits of the interferents ions (error $\pm 5 \%$ ). The results demonstrate that the presence of large amounts of species commonly present in water samples have no significant effect on the preconcentration of gold.

\section{Determination of gold in river water samples}

The method has been employed for determination of gold in Shoor river water Shahdad and Kohpayeh river water in Kerman. A 250.0 $\mathrm{mL}$ of water samples was adjusted to $\mathrm{pH} 1$ with nitric acid, filtered and analyzed by general procedure. The results are given in Table 4.

Spike recovery tests have also been performed using the real samples and recoveries in the range 101.4-103.7\% (Table 4) were obtained that demonstrating good accuracy of the method and the capability to determine gold at trace levels in various water samples.

\section{Comparison of present method with the other reported methods}

A comparison of the represented method with the other reported methods ${ }^{2,27-31}$ was showed in Table 5. As shown in Table 5, the 
Table 3. Tolerance limit of foreign ions

\begin{tabular}{cc}
\hline Foreign ions & Interferent/Au(III) ratio \\
\hline $\mathrm{Na}^{+}, \mathrm{K}^{+}, \mathrm{Ca}^{2+}, \mathrm{Mg}^{2+}$ & 10000 \\
$\mathrm{CH}_{3} \mathrm{COO}^{-}$ & 7000 \\
$\mathrm{H}_{2} \mathrm{PO}_{4}^{-}, \mathrm{HPO}_{4}^{2-}, \mathrm{NH}_{4}^{+}$ & 4000 \\
$\mathrm{Co}^{2+}, \mathrm{Cu}^{2+}$ & 1000 \\
$\mathrm{Mn}^{2+}, \mathrm{Ni}^{2+}$ & 500 \\
$\mathrm{Fe}^{2+}, \mathrm{Fe}^{3+}$ & 400 \\
$\mathrm{Ag}^{+}, \mathrm{Sb}^{3+}, \mathrm{Cd}^{2+}$ & 300 \\
$\mathrm{Cr}^{3+}, \mathrm{Al}^{3+}, \mathrm{Pd}^{2+}, \mathrm{Sn}^{2+}$ & 200 \\
\hline
\end{tabular}

Conditions were the same as Figure 1.

Table 4. Determination of gold in river water samples

\begin{tabular}{lccc}
\hline \multirow{2}{*}{ Sample } & \multicolumn{2}{c}{ Gold amount $\left(\mathrm{ng} \mathrm{mL}^{-1}\right)^{\mathrm{a}}$} & \multirow{2}{*}{ Recovery\% } \\
\cline { 2 - 3 } & Added & Found & \\
\hline \multirow{2}{*}{ Shoor river in } & 0.0 & $\mathrm{BLR}^{\mathrm{b}}$ & ---- \\
Shahdad & 5.00 & $5.15 \pm 0.21$ & 103.0 \\
& 10.0 & $10.37 \pm 0.48$ & 103.7 \\
Kohpayeh river in & 0.0 & $\mathrm{BLR}$ & --- \\
Kerman & 5.00 & $5.18 \pm 0.24$ & 103.6 \\
& 10.0 & $10.14 \pm 0.51$ & 101.4 \\
\hline
\end{tabular}

${ }^{a}$ Average of 4 determination, \pm standard deviation. ${ }^{b}$ Below of linear range

characteristic data of the proposed method are compared with those reported in the literature. The detection limit obtained by the proposed method is comparable to those in reported methods.

Table 5. Comparison of the reported methods with the proposed method

\begin{tabular}{lccc}
\hline Sample & Procedure/Detection method & $\begin{array}{c}\text { Detection limit } \\
\left(\mathrm{ng} \mathrm{mL}^{-1}\right)\end{array}$ & Ref. \\
\hline $\begin{array}{l}\text { Water, } \\
\text { pharmaceuticals }\end{array}$ & SPE/FAAS & 1.0 & 27 \\
$\begin{array}{l}\text { Ores } \\
\text { Minerals, } \\
\text { anode slime }\end{array}$ & SPE/UV-Vis Spectrophotometry & $18 \mathrm{ng} \mathrm{g}^{-1}$ & 28 \\
$\begin{array}{l}\text { High purity iron } \\
\text { Ores }\end{array}$ & SPE/FAAS & 10 & 29 \\
$\begin{array}{l}\text { Urine, } \\
\text { pharmaceuticals }\end{array}$ & Vapor Generation/ETAAS & 0.8 & 31 \\
water & Kinetic Spectrophotometric & 5.5 & 2 \\
\hline
\end{tabular}

\section{CONCLUSION}

The proposed SPE method based on nanoclay closite 15 A modified with rhodanine is a simple, rapid, selective and reproducible method for the separation, preconcentration and determination of gold ions. The time taken for the separation and analysis of gold is at most $20 \mathrm{~min}$. The method can be successfully applied to the separation and determination of gold in real samples. Additionally, it shows high selectivity, adequate detection limit, no dangerous reagents or unique chemicals used and good precision and accuracy in all cases.

\section{REFERENCES}

1. Hamilton, T. W.; Ellis, J.; Florence, T. M.; Anal. Chim. Acta 1983, 148, 225.

2. Rancic, S. M.; Nikolic-Mandic, S. D.; Mandic, L. M.; Anal. Chim. Acta 2005, 547, 144.

3. Zuoto, Z.; McCreedy, T.; Anal. Chim. Acta 1999, 401, 237.

4. Medved, J.; Bujdos, M.; Matus, P.; Kubova, J.; Anal. Bioanal. Chem. 2004, 379, 60

5. Kanicky, V.; Otruba, V.; Mermet, J. M.; Talanta 1999, 48, 859.

6. Kavakli, C.; Zvatan, N. O.; Tuncel, S. A.; Salih, B.; Anal. Chim. Acta 2002, 464, 313

7. Dressler, V. L.; Pozebon, D.; Curtius, A.; Anal. Chim. Acta 2001, 438, 235

8. Tang, B.; Zhang, H.; Wang, Y.; Anal. Chim. Acta 2004, 525, 305.

9. Nat, A.; Ene, A.; Lupu, R.; J. Radioanal. Nucl. Chem. 2004, 261, 179.

10. Messerschmidt, J.; von Bohlen, A.; Alt, F.; Klockenkamper, R.; Analyst 2000, 125, 397

11. De Godoi Pereira, M.; Arruda, M. A. Z.; Microchim. Acta 2003, 141, 115.

12. Rees, K. L.; van Deventer, J. S.J.; Hydrometallurgy 2000, 58, 151

13. Yu, M.; Sun, D.; Huang, R.; Tian, W.; Shen, W.; Zhang, H.; Xu, N.; Anal. Chim. Acta 2003, 479, 225.

14. Afzali, D.; Mostafavi, A.; J. AOAC Int. 2008, 91, 1430.

15. Pinnavaia, T. J.; Science 1983, 220, 365.

16. Deer, W. A.; Howie, R. A.; Zussman, J.; An Introduction to the Rock forming Minerals, ELBS Longman: England, 1985.

17. Ohtsuka, K.; Hayashi, Y.; Suda, M.; Chem. Mater. 1993, 5, 1823.

18. Mellah, A.; Chegrouche, S.; Water Res. 1997, 31, 621.

19. Echeverria, J. C.; Churio, E.; Garrido, J.; Clays Clay Miner. 2002, 50, 614.

20. Yavuz, O.; Altunkaynak, Y.; Guzel, F.; Water Res. 2003, 37, 948

21. Kara, M.; Yuzer, H.; Sabah, E.; Celik, M. S.; Water Res. 2003, 37, 224.

22. Alvarez-Ayuso, E.; Garcia-Sanchez, A.; Clays Clay Miner. 2003, 51, 475.

23. Lin, S. H.; Juang, R. S.; J. Hazard. Mater. 2002, 92, 315

24. De Leon, A. T.; Nunes, D. G.; Rubio, J.; Clays Clay Miner. 2003, 51, 58.

25. Ko, C. H.; Fan, C.; Chiang, P. N.; Wang, M. K.; Lin, K. C.; J. Hazard. Mater. 2007, 14, 275.

26. Richards, S.; Bouazza, A.; Appl. Clay Sci. 2007, 37, 133.

27. Bagheri, M.; Mashahadiziadeh, M. H.; Razee, S.; Talanta 2003, 60, 839.

28. Al-Merey, R.; Hariri, Z.; Abu Hilal, J.; Microchem. J. 2003, 75, 169.

29. Pu, Q.; Liu, P.; Sun, Q.; Su, Z.; Microchim. Acta 2003, 143, 45.

30. Itagaki, T.; Ashino, T.; Takada, K.; Fresenius J. Anal. Chem. 2000, 368, 344

31. Ma, H.; Fan, X.; Zhou, H.; Xu, S.; Spectrochim. Acta, Part B 2003, $58,33$. 